\title{
Tradisi Badantam dalam Alek Perkawinan (Kajian Fungsionalisme Struktural)
}

\section{"Badantam" Tradition in "Alek" of Marriage (Study of Structural Functionalism)}

\author{
Wita Harmaini, Khairil Anwar, Pramono \\ pramono@hum.unand.ac.id \\ Universitas Andalas
}

\begin{abstract}
ABSTRAK
This article contains a brief description of the badantam tradition that lives in the Kampung Kandang village in Pariaman. Badantam tradition is part of a tradition that lives in the community, which is in the traditional wedding ceremony. Badantam tradition aims to raise funds from the community donations of someone who married his child.

Through this description, obtained the meaning contained in this tradition badantam. The meaning of badantam tradition includes self-esteem, social control, and cooperation.
\end{abstract}

Keywords: Badantam, Traditional Ceremony, Function, Meaning

\section{PENGANTAR}

Tradisi badantam merupakan sebuah tradisi yang bertujuan untuk mengumpulkan dana. Pada tradisi itu, orang-orang berlomba dan bersaing untuk memberikan sumbangan sebanyak-banyaknya, misalnya momentum pesta perkawinan atau alek kawin, momentum pembangunan sarana ibadah (masjid, musala, surau) dan sarana umum lainnya.

Badantam mengandung prinsip kerja sama antara sejumlah warga masyarakat dalam kehidupan sosial untuk menyelesaikan suatu pekerjaan tertentu yang dianggap berguna untuk kepentingan bersama. Badantam sebagai salah satu bentuk usaha manusia untuk saling membantu tanpa imbalan langsung yang diterima namun dihasilkan untuk kepentingan bersama atau kepentingan umum. Badantam merupakan kearifan budaya lokal yang memiliki nilai-nilai gotong royong, kebersamaan, persatuan, kesatuan, sukarela, sosialisasi, kekeluargaan serta tolong- menolong antar sesamanya.

Pariaman merupakan wilayah rantau di Minangkabau yang memiliki sejarah penting dalam konteks penyebaran agama Islam. Syekh Burhanuddin merupakan tokoh ulama yang berperan penting dalam penyebaran Islam di Sumatera Barat. Perannya sebagai tokoh yang kuat dalam berdakwah, menjadikan Pariaman dikenal sebagai ikon wilayah rantau yang memiliki sejarah yang patut diperhitungkan dalam konteks islamisasi di Sumantra Barat. Berdasarkan hal tersebut masyarakat Pariaman hidup dalam konteks yang islami sebagai wujud dari syarak mandaki, adat manurun. 
Selain dikenal sebagai wilayah yang kental dengan nuansa keislaman, Pariaman juga dikenal sebagai wilayah yang multikultur. Tidak hanya masyarakat asli Minangkabau yang mendiami wilayah ini, namun berbagai suku bangsa lainnya hidup berdampingan dengan harmonis sejak zaman dahulu di Pariaman.

Pengaruh Islam yang kuat di Pariaman telah menyatu dalam kehidupan masyarakat dari berbagai suku bangsa yang mendiami wilayah ini. Sebagai wilayah yang multikultural dapat dilihat dari perkampunganperkampungan yang didiami oleh suatu suku bangsa yang sudah lama hidup secara turun temurun di Pariaman. Seperti adanya perkampungan yang bernama Kampuang Kaliang yang dihuni oleh masyarakat keturunan India yang beragama Islam, Kampung Jawa yang mayoritas masyarakatnya merupakan keturunan Jawa.

Begitu juga dengan Kampuang Cino yang konon dahulunya didiami oleh etnis Cina, namun karena adanya persoalan dengan masyarakat Pariaman sehingga mengharuskan etnis Cina untuk keluar dari Pariaman, dan hingga saat ini tidak ditemui keturunan Tiongkok yang berdomisili di Pariaman.

Pariaman memiliki corak budaya yang unik dan khas. Pola pemerintahan tradisionalnya juga berbeda dari pola pemerintahan di nagari dataran tinggi Minangkabau, yang dipimpin oleh panghulu (ninik mamak nagari). Rantau Pariaman menggunakan pola kepemimpinan rajo (Amelia, 2004; Naim, 2013; Navis, 1984). Sistem perkawinan pun berbeda, yaitu kawin bajapuik, yang dalam pemeo masyarakat Pariaman dikenal dengan istilah "membeli mempelai laki-laki”.

Sistem perkawinan di Pariaman juga unik, baik dalam pola peminangan maupun atribut-atribut seremonial lainnya. Sehingga muncul stereotip bahwa laki-laki dibeli. Badantam ada di dalam tradisi perkawinan di Pariaman khususnya di Kampung Kandang, Pariaman Timur. Pada sisi lain keunikan yang menonjol dari tradisi badantam adalah terdapatnya prinsip materialisme masyarakat Pariaman, yang menjadi kebiasaan bagi masyarakat. Hal itu diwujudkan dengan rasa tanggung jawab yang kuat dalam pendanaan.

Keberadaan tradisi badantam memiliki variasi antara satu nagari (kesatuan wilayah setingkat desa) dengan nagari lain. Di beberapa nagari, tradisi itu disebut badoncek, baretong, dan pasirihan. Dalam prosesi pelaksanaan momentum alek kawin (pesta perkawinan), ada yang melaksanakan pada hari pertama dan hari kedua alek.

Sampai dekade terakhir, tradisi badantam di Rantau Pariaman (saat ini meliputi Kota dan Kabupaten Padang Pariaman) telah melembaga secara sosial, hampir tidak ada momentum yang tidak dilengkapi dengan acara badantam. Akan tetapi, dalam beberapa tahun terakhir ini, tradisi tersebut cenderung mulai surut. Hal itu disebabkan oleh banyaknya kritik terhadap tradisi tersebut. Kritik yang dimaksud berasal dari kelompok lain di luar komunitas rantau Pariaman, dari organisasi masyarakat keislaman modern, dan lainnya. Argumentasi pengkritik antara lain: (1) tradisi tersebut tidak sesuai dengan ajaran Islam yang menganjurkan berinfak secara diam-diam sehingga tidak termasuk sikap riya, (2) tudingan bahwa masyarakat Pariaman pendukung tradisi badantam sebagai kelompok masyarakat yang suka pamer, dan (3) berbagai pandangan lainnya. Akibatnya, generasi muda sudah terbuka, yang telah menempuh pendidikan tinggi dan modern sehingga cenderung lebih kritis mulai meninggalkan bahkan menentang adanya tradisi tersebut.

Menurut salah seorang tokoh di Pariaman, Masrudin (59 tahun), ada dampak lain yang muncul pada tradisi ini, yaitu dari sistem kepengurusan tidak sesuai dengan aturan adat yang disepakati. Namun, tradisi ini bisa saja hilang hanya karena uang. Hal ini disebabkan pemberian uang kepada masyarakat yang tidak disiplin dengan 
kepengurusan, sehingga terjadinya perpecahan antara niniak mamak dan pengurus lainnya. Hal inilah yang menjadi sebab hilangnya tradisi badantam dan sistem kepengurusan serta hubungan kekerabatan (wawancara, 13 Februari 2018).

Selain itu, badantam bisa hilang disebabkan adanya pendatang dari luar yang menetap di kampung tersebut, tetapi belum memenuhi syarat-syarat adat di nagari, seperti mengisi carano yang wajib dipenuhi. Oleh karena itu ketika seorang pendatang melaksanakan acara alek, dia tidak bisa melaksanakan badantam dan babaua yang telah disepakati bersama masyarakat setempat sebelumnya.

Kondisi ini menyebabkan tradisi badantam di wilayah Padang Pariaman terancam punah. Padahal tradisi badantam mengandung nilai-nilai kegotongroyongan dan kearifan budaya lokal yang tidak mampu dilihat oleh para pengkritik secara lebih baik. Selain itu, di dalam tradisi badantam juga terdapat nilai-nilai integritas, kedisiplinan, etos kerja, kerja keras, tanggung jawab dan semangat bergotong-royong. Bila dibiarkan, tentulah tradisi itu akan hilang bersama nilai-nilai yang dimaksud. Padahal di beberapa tempat di luar Sumatera Barat, tradisi serupa yaitu badoncek masih dilaksanakan (Deliani, 2017; Muslim, 2016; Putra, 2016). Oleh sebab itu, penelitian terhadap badantam ini penting dan mendesak untuk dilakukan. Asumsi dasar inilah yang mendasari penelitian.

Pelaksanaan badantam dalam alek perkawinan juga didasari oleh suatu keyakinan yang dimiliki oleh masyarakat tentang harga diri. Harga diri terlihat ketika seorang sumando tidak ikut menyumbang dalam pelaksanaan badantam untuk adik istrinya, maka dia akan merasa malu sebagai seorang sumando yang berada di kampung itu. Seorang sumando juga akan merasa dikucilkan dan segan ketika berhadapan dengan masyarakat sekitarnya. Hal ini sudah menjadi karakter orang Minangkabau, yang sudah tertanam ke dalam diri mereka bahwa, harga diri itu penting dalam kehidupan bermasyarakat.

Tradisi badantam yang terdapat pada alek perkawinan menujukkan persatuan keluarga, keluarga inti, keluarga besar, urang sumando dan masyarakat. Selain itu, badantam bertujuan untuk mengurangi beban dari pihak mempelai wanita untuk melaksanakan perkawinan di Pariaman. Tradisi badantam juga merupakan upaya dari masyarakat agar tradisi uang jemputan eksistensinya dapat dipertahankan. Di sisi lain, pernikahan bajapuik saat ini memengaruhi makna dan esensi dari proposal uang sehingga beberapa calon pengantin pria ternyata hanya mengharapkan uang proposal dari pernikahan, karena mereka menganggap uang itu sebagai properti pra-nikah. Bahkan, dilihat dari adat (tradisi), makna dan esensi dari pemberian uang proposal, itu diberikan dengan tujuan untuk menjadi milik bersama mereka (Muslim, 2016).

Oleh karenanya, penelitian tradisi daerah seperti halnya tradisi badantam perlu dilaksanakan, sebab tradisi badantam merupakan budaya yang dapat berkontribusi dalam kebudayaan nasional, serta dapat membantu memperkuat solidaritas sosial dan sikap toleransi dalam hidup bermasyarakat. Kritikan dari luar komunitas rantau Pariaman (organisasi masyarakat keislaman) dan generasi muda Pariaman dikhawatirkan dapat mengganggu keberadaan tradisi tersebut.

Badantam dalam alek perkawinan mengungkap nilai-nilai kegotongroyongan yang menjadi kearifan budaya lokal masyarakat setempat. Nilai-nilai tersebut penting digali dan diungkapkan agar tidak terkikis oleh berbagai pandangan negatif, seperti yang diuraikan oleh berbagai pengaruh internal dan eksternal lainnya. Sebaliknya nilai-nilai budaya tersebut justru perlu direvitalisasi. 


\section{KERANGKA TEORI DAN METODOLOGI}

penelitian ini menggunakan teori fungsionalisme struktural yang dikembangkan oleh Radcliffe-Brown. Radcliffe-Brown (dalam Endraswara, 2003) menyatakan bahwa fungsionalisme struktural adalah model penelitian yang memperhatikan keterkaitan antara unsur budaya dalam memenuhi fungsinya. Unsur budaya memiliki makna yang tersirat beserta fungsi khas tergantung hubungan di antara unsur-unsur yang ada. Struktur sosial tersebut menjadi suatu hubungan yang saling bersangkutan. Redcliffe-Brown merasa bahwa berbagai aspek perilaku sosial bukanlah berkembang untuk memuaskan kebutuhan sosialnya, tetapi justru mempertahankan struktur sosial masyarakat. Struktur sosial masyarakat adalah seluruh jaringan dari hubungan sosial yang ada (Endraswara, 2003).

Tujuan kajian-kajian struktural fungsionalisme adalah untuk membangun suatu sistem sosial, struktur sosial, melalui pengajian terhadap pola hubungan yang berfungsi antara individu-individu, antara kelompokkelompok, atau antara institusi-institusi sosial di dalam suatu masyarakat, pada suatu kurun masa tertentu.

Asumsi dasar teori fungsionalisme struktural adalah adanya kesadaran masyarakat dalam menguatkan kebutuhan manusia dengan lingkungan sekitar demi mengukuhkan struktur sosial masyarakatnya. Sementara itu jika dikaji lebih dalam maka dari unsur-unsur badantam akan terlihat fungsi untuk membangun suatu ketahanan dalam memperkuat struktur badantam itu sendiri. Oleh karena itu, fungsionalisme lebih menekankan pada tingkat perilaku sosial masyarakat terhadap struktur sosialnya.

Penelitian ini dilakukan di Kampung Kandang, Pariaman Timur. Kegiatan penelitian ini meliputi tiga tahapan, yaitu tahap penyediaan atau pengumpulan data, tahap analisis data dan tahap penyajian data. Penyediaan atau pengumpulan data badantam dilakukan dengan menggunakan teknik observasi, perekaman atau wawancara dan studi pustaka. Penulis merekam tradisi badantam yang dilaksanakan di alek perkawinan Piak Pirang pada malam hari tanggal 14 Agustus 2017.

Untuk mendapatkan informasi lisan yang lebih mendalam dan lengkap, berkaitan dengan prosesi digunakan teknik wawancara (Bungin, 2006). Wawancara dimaksudkan untuk mendapatkan penjelasan mengenai orang, kejadian, kegiatan, organisasi, motivasi, perasaan dan sebagainya. Wawancara dalam satu penelitian bertujuan untuk mengumpulkan keterangan secara lisan dari informan. Dalam pencarian data melalui wawancara, yang paling menentukan adalah informan. Informan diusahakan meliputi semua komponen dalam masyarakat. Untuk menunjang keabsahan data, dilakukan wawancara dengan beberapa pihak yang terkait untuk informasi yang diperlukan yaitu Niniak Mamak, Kapalo mudo, Alim ulama, Kapalo desa, Cadiak Pandai dan masyarakat. Pemilihan informan dilakukan dengan teknik snowball sampling, yaitu berdasarkan informasi seorang informan pangkal seterusnya menuju informan-informan yang direkomendasi oleh informan sebelumnya sampai mendapatkan data penuh (Endraswara, 2003). Informasi digali dari pelaksana badantam, pada alek perkawinan di Kampung Kandang Pariaman Timur dan wawancara dengan tokoh masyarakat, pengamat, dan masyarakat luas.

Setelah data diperoleh, tahap berikutnya adalah analisis data. Menganalisis semua data ke dalam bentuk mentranskripsi dan memilah melalui rekaman ke dalam bentuk tulisan sehingga tulisan tersebut dapat diterjemahkan dalam analisis unsur-unsur badantam, fungsi dalam sistem sosial atau kebudayaan di Pariaman. Data tersebut di perbaiki secara optimal selanjutnya data yang telah diperbaiki terlihat lebih sederhana dan lengkap serta mudah dipahami oleh pembaca. 


\section{HASIL DAN PEMBAHASAN}

\section{SEJARAH BADANTAM}

Di dalam sejarah, tradisi badantam memang sulit ditelusuri, hal tersebut disebabkan tidak adanya sumber tertulis yang bisa dijadikan bukti. Berdasarkan hasil wawancara dengan salah seorang tokoh masyarakat, Masrudin (59 tahun) pada tanggal 13 Februari 2018 mengatakan:

"Dantam ko alah ado sajak tahun 1945 an nan pado dahulunyo dek nenek moyang kito nan masalahnyo. Kan dek kito ko ado nan kayo jo nan bansaik, jadi tibo di nan bansaik baralek tantu indak bisa dek inyo mainjek baban barek basingguluang batu doh. Mako dari itu diadokanlah dantam di ateh namo manuruik korong jo desa. Jadi, diundanglah masyarakaik banyak datang ka rumah kito. Umpamonyo ado nan ma adokan suatu pahelatan perkawinan anak kamanakan untuak manjapuik (mambali) marapulai, tantu indak talok dek nyo mancari dana doh. Mako dari itu, diadokanlah dantam untuak maringanan baban nan barek ko. Bak kato urang tuo-tuo dulu "tambah-tambah bali kunik, tukuak-tukuak bali lado”. Mako dari ikolah kito bantu pagotongroyongan basamo untuak masyarakaik kito”.

Dantam ini sudah ada sejak tahun 1945an yang pada dahulunya oleh nenek moyang kita, masalahnya kita ini ada yang kaya dan miskin. Jadi, ketika yang miskin melaksanakan perhelatan perkawinan, tentu mereka tidak mampu mengangkat beban berat bersinggulung batu. Maka dari itu, diadakanlah dantam atas nama menurut korong dan desa. Jadi, diundanglah masyarakat banyak untuk datang ke rumah kita. Umpamanya ada yang mengadakan suatu perhelatan perkawinan anak dan kemenakan untuk membeli marapulai, tentu tidak sanggup bagi mereka untuk mencari dana. Maka dari itu diadakanlah dantam untuk meringankan beban yang berat ini. Seperti kata orang tua-tua dahulu "tambah-tambah beli kunyit, tambah-tambah beli cabe". Maka dengan inilah kita bantu dengan cara bergotong- royong bersama untuk masyarakat kita.

Diyakini tradisi badantam sudah ada sejak sebelum kemerdekaan RI. Tradisi ini pada dasarnya merupakan sebuah tradisi sosial yang bersifat gotong royong dalam membantu dunsanak atau pun masyarakat dalam meringankan bebannya terhadap upaya mainjek baban nan barek basingguluang batu sebab, budaya di Pariaman yang pada umumnya terkenal dengan kawin bajapuik.

Di Pariaman, pihak perempuan yang akan melangsungkan pernikahannya memang memerlukan biaya yang cukup banyak. Mulai dari menyediakan uang jemputan dan uang hilang hingga menyediakan biaya yang berkenaan dengan perlengkapan untuk kamar pengantin dan biaya-biaya lainnya. Mengingat beratnya beban yang harus ditanggung oleh pihak perempuan inilah yang mendasari munculnya tradisi badantam di Pariaman.

Badantam juga merupakan wujud persatuan masyarakat atas nama korong dan desa yang disepakati secara bersama dengan mengundang seluruh masyarakat desa untuk hadir kerumah sanak saudara yang akan melaksanakan acara alek perkawinan. Sebagai bentuk kemudahan bagi masyarakat dalam mengumpulkan dana untuk sekedar “manambah-nambah bali lado, dan tukuak- tukuak bali kunik”. Dalam bentuk barek samo dipikua ringan samo di jinjiang. Tradisi ini hidup di tengah-tengah masyarakat Pariaman pada umumnya dan eksistensinya terus dipertahankan hingga hari ini.

\section{PELAKSANAAN DAN PROSESI BADANTAM}

Acara badantam dimulai pada malam hari, setelah acara resepsi pernikahan sekitar pukul $20.00 \mathrm{Wib}$, sebelum anak daro diantar manjalang ke rumah pihak marapulai. Pada saat itu semua anggota keluarga, kerabat 
dan masyarakat sudah berkumpul, dan acara badantam pun dimulai. Berakhirnya acara badantam tergantung pada jumlah yang hadir untuk pengumpulan dana.

Badantam ini diadakan setiap kali acara alek perkawinan di Pariaman pada umumnya. Masyarakat senantiasa berpartisipasi untuk mengumpulkan dana bantuan dari seluruh kerabat secara kekeluargaan. Pada dasarnya tradisi badantam tersebut adalah sebuah tradisi sosial bergiliran.

Acara badantam biasanya dilaksanakan pada patang alek, malam hari setelah salat isya. Hal ini disebabkan masyarakat pada umumnya bekerja di siang hari bertani, berladang, membuat batu bata, pegawai, dan berdagang.

Suasana dalam acara badantam ini biasanya ramai dihadiri oleh masyarakat dan tamu undangan. Mereka berkumpul dan berbincang-bincang sambil menunggu giliran menyerahkan uangnya untuk diumumkan.

Tahapan dan tata cara pelaksanaan badantam yang biasanya dilakukan adalah sebagai berikut.

1. Berkumpul dan berunding di rumah sipangka (tuan rumah)

Semua perangkat berkumpul pada sebuah meja panjang (tempat rundiangan niniak mamak) yang telah disediakan oleh tuan rumah yang melaksanakan alek. Para niniak mamak, berunding dan memanggil tuan rumah selaku silang nan bapangka (tuan rumah) untuk membuka uang yang ada di beleak (kotak rumah adat) dan kampia (tas) untuk memulai badantam. Setelah perundingan itu selesai, maka dimulailah proses badantam yang bertujuan untuk mengumpulkan dana dalam membantu sanak saudara yang melaksanakan alek.

2. Pembukaan pasambahan kato

Adapun bentuk teks pasambahan pembuka kata oleh janang (pembawa acara) yaitu:

"Kami maimbau seluruh masyarakat desa Kampuang Kandang yang diminta hadir ka rumah dunsanak kito, nan ba baban barek basingguluang batu, barek samo kito pikua, ringan samo kito jinjiang. Iyolah dek kito alah duduak basamo, kito ka mulai baretong, ba a dek kito basamo? Kito mulai dantam ko lai? Iyo, dek karano alah cukuik, niniak mamak lah ado, alim ulama lah ado, kapalo desa alah ado, labai lah cukuik, kito imbau atau kito mintak kampia lai? iyo. Ba a dek kito basamo dek kampia alah di bukak, beleak jo kampia alah kito atak an di ateh meja niniak mamak, Ba a dek kito ko nan babunyi "sairiang tuga jo cicia" dantam kito turunan sakali-kali nan mokasuiknyo nan samo masak gambia jo kapunduang, disakabekkan paku jo bayam? iyo.

Kami menghimbau kepada seluruh masyarakat desa Kampung Kandang yang diminta hadir ke rumah sanak saudara kita yang berbeban berat bersinggulung batu, berat sama dipikul, ringan sama dijinjing. Maka dari itu kita sudah duduk bersama, kito akan mulai menghitung uang. Bagaimana menurut kita bersama? Apakah kita mulai menghitung uang? Iya, dikarenakan semuanya sudah cukup segala niniak mamak ada, alim ulama, kepala desa juga ada, para ulama sudah cukup kita panggil atau kita minta uangnya lagi? Iya, bagaimana menurut kita karena tas telah dibuka, beleak sudah diletakkan di atas meja niniak mamak. Bagaimana menurut kita bersama yang berbunyi "seiring pancang dan menyatu, dantam kita turunkan sekali-kali yang maksudnya sama masak gambir dan kepundung, diikatkan paku dan bayam? iya.

Janang meminta kepada seluruh masyarakat yang hadir beserta silang nan bapangka untuk bersama ikut menyaksikan dan menghitung jumlah uang yang berada dalam beleak dan kampia serta menghimbau kepada masyarakat untuk ikut berpartisipasi dalam meringankan beban sipangka dengan cara badantam.

\section{Badantam}


Setelah kata pembuka selesai, maka janang mulai mengajak masyarakat untuk mengeluarkan uang sebanyak-banyaknya. Uang yang diberikan masyarakat tidak ditentukan nominalnya, tetapi seberapa mampu masyarakat untuk menyumbang.

Setelah semua dana terkumpul, baik itu uang yang berada dalam beleak dan kampia serta hasil sorakan (spontanitas) yang disatukan, semuanya diumumkan kepada silang nan bapangka dan masyarakat setempat. Kemudian janang memberitahukan hasil uang dantam dari kumpulan uang yang ada di kampia dan beleak, termasuk hasil sorakan hari ini yang didapat dengan jumlah 20 juta rupiah. Ungkapan tersebut adalah :

"Untuak kasadonyo ateh namo masyarakat desa Kampuang Kandang dana dantam yang didapek pado kini ko, sabanyak 20 juta rupiah. Tarimo kasih untuak masyarakat kito yang alah dapek hadir dalam mambantu baban nan barek ko".

Untuk semuanya atas nama masyarakat desa Kampung Kandang. Dana dantam yang didapat pada saat ini, sebanyak 20 juta rupiah. Terima kasih untuk masyarakat kita yang telah dapat hadir dalam membantu beban yang berat ini.

Para niniak mamak menghitung uang yang ada dalam beleak dan kampia serta hasil sorakan yang terkumpul hari ini untuk diumumkan, kepada seluruh masyarakat. Kemudian meminta terima kasih kepada masyarakat yang dapat hadir serta ikut berpartisipasi untuk membantu beban berat sipangka tersebut.

4. Penyerahan dana kepada sipangka

Dana yang diperoleh kemudian diserahkan kepada tuan rumah (sipangka). Sebelumnya uang dantam dikeluarkan sebanyak dua ratus ribu rupiah oleh niniak mamak dan dibagikan kepada perangkatnya sebanyak seratus ribu rupiah, sedangkan untuk urang salapan juga diberikan sebanyak seratus ribu rupiah. Uang tersebut sebagai tanda basa-basi atau uang rokok untuk semua perangkatnya. Kemudian janang mengemukakan pidato adat kepada masyarakat seperti :

"Ba a dek kito lai, dek karano patang kalamari, alek kito alah sampai, diama pacah, jadi dek kito kini, kok dicaliak tampak diimbau babuni, marupoi kepeang nan dapek dek kito basamo, tamasuak ipa-bisan, kalimaik simpang balahan, tamasuak korong jo nagari. Ba a dek kito lai kito sarahan kasilang nan bapangka”

Bagaimana menurut kita bersama, karena kemarin acara telah selesai, jika dilihat nampak, dipanggil berbunyi, menyerupai uang yang telah terkumpul oleh kita bersama, termasuk ipar besan, kalimat simpang belahan, termasuk korong dan nagari, bagaimana sebaiknya jika kita serahkan kepada tuan rumah.

Dalam pidato adat di atas maksud dan tujuan telah sampai kepada seluruh masyarakat yang ikut menyumbang, termasuk ipar besan, dan seluruh masyarakat bersangkutan dari korong dan nagari. Hasil uang dantam akan diserahkan kepada tuan rumah.

Penyerahan uang tersebut menggunakan pidato pasambahan yang dikemukakan oleh kapalo mudo:

“Ateh namo Darin yang ambo imbau, tapi sungguah Darin sipaiknyo silang nan bapangka, karakok nan bajunjuang, silang nan bapangka, niniak jo mamak, karakok nan bajunjuang, sarato urang sumando. Ba a dek ambo kini di ateh namoe duduak baniniak mamak, mangko diimbau Darin, bakato-kato urang Darin, gadang kayu gadang bahan, ketek kayu ketek bahan, sanak kamanakan jauah hampia, tamasuak jo ipa bisan. Ba a mangkonyo dek karano lah taungguak, dicaliak tampak babuni tadi, sabanyak 20 juta iko bana yang ambo sarahkan kasilang nan bapangka”. 
Atas nama Darin, sebagai tuan rumah, sirih yang berjunjung, tuan rumah, niniak dan mamak, sirih yang berjunjung beserta orang sumando. Bagaimana pendapat kita bersama setelah rundingan duduk niniak mamak, oleh karena itu dipanggil Darin, seperti kata orang, besar kayu besar bahan, kecil kayu kecil bahan, sanak kemenakan jauh dekat, termasuk ipar dan besan. Karena semuanya sudah berkumpul yang terlihat nampak berbunyi. Sebanyak 20 juta inilah yang saya serahkan kepada tuan rumah.

Memanggil salah satu keluarga tuan rumah untuk menyerahkan uang hasil badantam yang diperoleh pada acara badantam tersebut, yang diwakili oleh mamak rumah dan disaksikan oleh seluruh unsur masyarakat yang hadir. Niniak mamak pun mengingatkan kepada tuan rumah bahwa jika banyak rezeki, bantulah saudara serta masyarakat. Pada saat badantam inilah bisa membantu keluarga yang melaksanakan alek perkawinan. Silang nan bapangka juga menerima jawaban dari niniak mamak, yang berupa balasan:

\begin{abstract}
"Barupo dek si Asan namoe ko a, di ateh namoe nan diimbau silang nan bapangka, karakok nan bajunjuang, sagalo urang sumando. Rupo e, kok mamintak aghi nan saaghi, malam samalam, dek mamak atau korong jo kampuang, ba a gati, ba alam laweh ba padang leba, lah diagiah kandak ambo, ruponyo tibo di malam e kini dan siang e tadi. kok basicapek namoe nan mudo matah, dek badantam kok tambah-tambah bali kunik, tolong-tolong bali lado, rupoe alah ta onggok sabanyak 20 juta. Ko nan ba imbauan mangkek ambo, tapi sungguah pun ambo surang, sipaik e sagalo urang sumando, kan baitu?iyo.
\end{abstract}

Kepada si Asan, atas nama tuan rumah, sanak saudara, beserta semua orang sumando. Ternyata, jika diminta waktu sehari dan semalam, mamak atau korong dan kampung, bagaimana berpikiran luas, berpandangan lebar, yang telah memenuhi permintaan saya, ternyata telah datang saatnya siang tadi. Alangkah baiknya dipercepat, karena badantam ini berfungsi untuk menambah beli kunyit, tolong-tolong beli cabai, rupanya sudah terkumpul urang sebanyak 20 juta. Inilah yang disampaikan kepada saya, tetapi sungguh pun saya sendiri, sifatnya segala orang sumando, bukankah seperti itu? Iya

Setelah uang badantam terkumpul, maka perwakilan dari tuan rumah, sanak saudara termasuk orang sumando tuan rumah memberikan ucapan terima kasih kepada para niniak mamak yang telah meluangkan waktunya dalam memberikan kesempatan kepada tuan rumah untuk melaksanakan badantam. Selain membicarakan masalah waktu, juga membicarakan mengenai hasil uang yang terkumpul untuk tuan rumah sebanyak 20 juta rupiah yang telah diserahkan kepada sipangka.

\title{
ELEMEN YANG TERLIBAT DALAM BADANTAM
}

Sebagai sebuah tradisi yang tumbuh dan berkembang di kalangan masyarakat, badantam melibatkan berbagai unsur lapisan masyarakat. Adapun orang-orang yang hadir dan terlibat dalam acara badantam antara lain ampek jinih, urang salapan, pemuda dan masyarakat. Urang ampek jinih adalah orang yang terdiri dari empat jenis yaitu urang tuo, cadiak pandai, kapalo mudo, imam katik dan labai pegawai.

\section{Urang Ampek Jinih}

Urang ampek jinih adalah orang yang terdiri dari empat jenis yaitu urang tuo, cadiak pandai, kapalo mudo, imam katik labai pegawai.

Urang tuo adalah orang yang dituakan dan ditunjuk dikampung tersebut. Urang tuo disini berfungsi sebagai pencatat nama-nama orang yang menyumbang. Cadiak pandai seperti ungkapan kusuik yang ka manyalasaian, artinya apapun yang terjadi dikampung itu (masalah) dialah orang yang menyelesaikannya. Cadiak pandai berperan sebagai menghitung uang yang telah terkumpul. 
Alim ulama bertugas sebagai perwakilan di saat pernikahan, beliau harus menghadiri perkawinan dari awal sampai akhir acara. Dia yang mengawasi acara selama badantam itu berlangsung. Kapalo mudo bertanggung jawab atas segala masalah yang terjadi di kampung tersebut. Kapalo mudo sebagai penyelesai adat dan mengurus segala urusan adat salah satunya acara badantam. Saat proses peminangan, pihak keluarga yang akan meminang marapulai harus baiyo dengan kapalo mudo dan meminta izin terlebih dahulu. Banyak pekerjaan kapalo mudo yang ditemukan di dalamnya. Dalam badantam kapalo mudo juga turut serta dalam menghitung uang yang berada dalam beleak. Dalam badantam, kapalo mudo juga berperan sebagai janang (pembawa acara dan tukang sorak).

\section{Urang Salapan}

Urang salapan adalah orang yang dituakan dikampung, terdiri dari 8 orang yaitu 4 kaum perempuan dan 4 kaum laki-laki. Urang salapan ditunjuk khusus untuk orang baralek. Di samping itu, urang salapan ini ditunjuk ketika malam mangukuih (malam pada hari pertama alek). Para niniak mamak menunjuk urang salapan yang terdiri dari 4 orang laki-laki. Empat orang ini bertugas untuk menjemput marapulai dan memasangkan tabia (tirai) yang berada dalam rumah.

Urang salapan juga terdiri dari 4 orang perempuan yang bertanggung jawab dalam alek perkawinan. Kaum perempuan bertugas mengatur ketersediaan makanan dan minuman selama alek berlangsung. Sebab, jika tidak ada urang salapan yang mengatur ketersediaan makanan, bisa mengakibatkan orang lain mudah masuk dan memberi racun (tubo) terhadap makanan tersebut. Seandainya tidak ada urang salapan orang yang keracunan jadi tanggung jawab tuan rumah. Oleh sebab itulah ditunjuk urang salapan sebagai penanggung jawab acara baralek.

\section{Kepala Desa}

Desa Kampung Kandang dipimpin Kepala desa yang memimpin masyarakat serta kepengurusan desa, baik dalam pembangunan, pemerintahan desa dan membina kehidupan masyarakat. Selain sebagai pemimpin di kampung tersebut, Kepala Desa juga terlibat dalam kepengurusan badantam sebagai perwakilan dan ikut menghitung uang yang ada di beleak dan uang hasil sorakan pada saat itu.

4. Masyarakat sekitar

Masyarakat sebagai tamu undangan terdiri dari pemuda dan unsur masyarakat lainnya. Pemuda sebagai generasi penerus dari sebuah tradisi yang ada secara umum menjadi bagian penting yang terlibat dalam tradisi badantam. Ketua organisasi pemuda yang terlibat dalam badantam bertugas sebagai membuka amplop yang ada dalam beleak.

\section{POSISI DAN FUNGSI BADANTAM}

Bagi masyarakat Pariaman umumnya, badantam merupakan bagian penting yang tidak dapat diubah dan dipisahkan dari masyarakat, karena tradisi badantam sudah menjadi bagian dari kehidupan mereka. Badantam memegang peranan penting dalam kehidupan bermasyarakat. Karena dengan adanya badantam akan mempermudah kerja sama dalam pengumpulan dana.

Badantam tumbuh dan berkembang sebagai suatu proses dari sebuah tradisi yang diwariskan secara turun temurun. Masyarakat menyadari keberadaan badantam sebagai faktor utama dalam pelaksanaan alek. Unsurunsur yang terdapat dalam badantam berfungsi untuk saling mengukuhkan struktur sosial dalam membangun badantam itu sendiri. Ketika fungsi tersebut disadari masyarakat maka makna yang terkandung pada tradisi badantam ini akan muncul. 
Tradisi badantam dirasa perlu dilaksanakan sebagai wujud pemberdayaan nilai-nilai yang berkembang ditengah masyarakat. Tradisi badantam mempunyai fungsi untuk mengumpulkan uang biaya baralek (berhelat pernikahan), silaturahmi, dan mengukuhkan struktur tradisi perkawinan di Pariaman

1. Mengumpulkan uang biaya baralek

Tradisi badantam ini merupakan suatu hasil budaya secara lisan yang diciptakan masyarakat demi kepentingan bersama. Jika dilihat dari segi kebutuhan, masyarakat sendiri ada yang kaya dan juga miskin. Miskin dalam konsep orang Minangkabau adalah miskin sosial dan miskin harta. Orang miskin harta berarti orang yang tidak mempunyai uang, sedangkan miskin sosial adalah orang yang tidak mau datang ke acara-acara kelompok terutama datang dalam acara baralek. Orang lebih memilih miskin harta dari pada miskin sosial. Dalam badantam orang tidak akan melihat berapa banyak uang yang disumbangkan, tetapi melihat partisipasinya saat datang mengumpulkan uang untuk biaya baralek. Di samping itu, badantam juga mempunyai makna sebagai pengakuan terhadap harga diri, kontrol sosial, dan kerja sama. Tradisi badantam dapat dibandingkan dengan tradisi badoncek yang juga terdapat di wilayah Padang Pariaman (Khalisa, 2016).

\section{Silaturahmi}

Silaturahmi tidak dapat dipisahkan dari tradisi badantam. Dengan adanya badantam, masyarakat akan mewujudkan sifat membantu dan berbaur di acara tersebut, mereka akan saling bertemu dengan masyarakat setempat dan juga masyarakat luar. Perkumpulan pada saat badantam akan memperlihatkan kekompakan masyarakat yang sebelumnya jarang bertatap muka. Makna dari silaturahmi ini adalah kebersamaan, saiyo sakato, saiyo samudiak, solidaritas, dan kerja sama.

3. Mengukuhkan struktur tradisi perkawinan di Pariaman

Perkawinan merupakan suatu cara dari manusia untuk mengembangkan keturunan oleh sebab itu setiap perkawinan harus memenuhi syarat tertentu baik berdasarkan hukum positif, agama dan hukum adat. Perkawinan bajapuik adalah suatu bentuk perkawinan yang terdapat di Minangkabau suku Pariaman, pihak wanita yang meminang pihak pria (Deliani, 2017; Sitompul, 2017). Tidak semua wanita di Pariaman mampu menyediakan uang jemputan, perlengkapan pengantin, biaya perlengkapan pelaminan dan bahan makanan untuk alek. Oleh karena itu maka bermusyawarahlah masyarakat serta para niniak mamak untuk menemukan solusi dalam mengurangi beban yang melaksanakan alek perkawinan di Pariaman (Putra, 2016). Setelah bermusyawarah maka disepakati diadakan tradisi badantam .

Badantam ini fungsinya untuk mempertahankan struktur tradisi perkawinan di Pariaman seperti tradisi perkawinan bajapuik yang perlu dipertahankan oleh masyarakat di Pariaman. Ketika unsur-unsur yang berkaitan dengan badantam itu berjalan dengan semestinya maka fungsi badantam itu disadari oleh masyarakat itu sendiri. Badantam ini juga dijadikan sebagai sarana untuk silaturahmi, kerja sama, kontrol sosial masyarakat, mencerminkan karakter Piaman baduya, dan menjadi tempat untuk meningkatkan harga diri, karena jika ada salah seorang masyarakat yang tidak ikut berpartisipasi dalam acara badantam maka akan dikenakan sanksi seperti dikucilkan oleh masyarakat.

Tradisi perkawinan yang ada di Pariaman memiliki perbedaan dengan daerah luar rantau Pariaman. Perbedaan tersebut terdapat pada proses perkawinan yang terlihat pada uang jemputan dalam tradisi perkawinan di Pariaman, untuk mempertahankan eksistensi dari uang jemputan tersebut. 


\section{PENUTUP}

Tradisi badantam merupakan sebuah tradisi yang bertujuan untuk mengumpulkan dana modal alek perkawinan di Pariaman, khususnya Desa Kampung Kandang. Badantam adalah sebagai bentuk persatuan masyarakat yang dibuat demi kepentingan bersama. Sehingga menjadikannya kebutuhan yang tidak dapat dipisahkan dan dihilangkan. Selain itu, tradisi badantam diadakan sebagai bentuk partisipasi masyarakat terhadap keluarga dan sanak saudara dalam meringankan beban. Di samping itu, ada beberapa prosesi yang terdapat dalam badantam; pertama berkumpul dan berunding dirumah sipangka, kedua, pembukaan pasambahan kato, ketiga, penyerahan dana kepada sipangka, keempat kesepakatan mamak rumah dengan sumandonya, kelima, makan bersama sebagai wujud kehormatan dan rasa terimakasih dan terakhir penutup.

\section{DAFTAR PUSTAKA}

Amelia, R. (2004). Tradisi Batagak Rajo di Kenagarian Kurai Taji Pariaman. Universitas Andalas.

Bungin, B. (2006). Analisis Data Penelitian Kualitatif. Jakarta: Raja Grafindo Persada.

Deliani. (2017). 'BAJAPUIK' TRADITION IN THE PARIAMAN PEOPLE'S MARRIAGE IN BINJAI CITY, NORTH SUMATRA. INTERNATIONAL JOURNAL ON LANGUAGE, RESEARCH AND EDUCATION STUDIES, 1(2), 187-198. Retrieved from http://jurnal.uinsu.ac.id/index.php/ijlres/article/view/1027

Endraswara, S. (2003). Metodologi Penelitian Kebudayaan. Yogyakarta: Gadjah Mada University Press.

Khalisa, L. (2016). Tradisi Badoncek dalam Adat Perkawinan Minangkabau Wilayah Pariaman di Kota Medan. Universitas Sumatera Utara, Medan. Retrieved from http://repositori.usu.ac.id/handle/123456789/6585

Muslim, H. (2016). KEDUDUKAN UANG JEMPUTAN DALAM PERKAWINAN BAJAPUIK PADA MASYARAKAT MINANGKABAU PARIAMAN DITINJAU DARI UNDANG-UNDANG NOMOR 1 TAHUN 1974 TENTANG. PREMISE LAW JURNAL, 2. Retrieved from https://jurnal.usu.ac.id/index.php/premise/article/view/12590

Naim, M. (2013). Merantau Pola Migrasi Suku Minangkabau. Yogyakarta: Gadjah Mada University Press.

Navis, A. A. (1984). Alam Terkembang Jadi Guru: Adat Dan Kebudayaan Minangkabau. Jakarta: Grafiti Press.

Putra, R. Z. (2016). Tradisi Uang Japuik dan Status Sosial Laki-Laki. Fakultas Syariah dan Hukum UIN Syarif Hidayatullah Jakarta, Jakarta. $\quad$ Retrieved from http://repository.uinjkt.ac.id/dspace/handle/123456789/32944

Sitompul, R. (2017). Perkawinan Bajapuik dan Konsekwensinya dalam Keluarga. JPPUMA: Jurnal Ilmu Pemerintahan Dan Sosial Politik Universitas Medan Area, 5(1), 9. https://doi.org/10.31289/jppuma.v5i1.997 